\title{
Accumulation of Some Heavy Metals in Plants and Soils Adjacent to Cairo - Alexandria Agricultural Highway
}

\author{
Taghred A. Hashim, H. H. Abbas*, I. M. Farid, O. H. M. El-Husseiny and M. H. \\ H. Abbas \\ Soils and Water Department, Faculty of Agriculture, Benha University, Egypt
}

\begin{abstract}
A UTOMOBILE exhausts are considered the main source of air pollution with heavy metals. Airborne pollutants are precipitated on soils surrounding highways causing serious ecological hazards. The current study aimed at evaluating levels of $\mathrm{Pb}, \mathrm{Ni}, \mathrm{Co}$ and $\mathrm{Cd}$ in surface $(015-\mathrm{cm})$ and subsurface $(1540-\mathrm{cm})$ soils nearby Cairo-Alexandria agricultural highway, and their accumulation in plants grown thereon. Seven locations were sampled at interval distances 50 meters on both sides of the highway road near Toukh city (Qualubya Governorate)._Cabbage and citrus plants were also sampled and separated into its parts. Results revealed that the investigated soils are contaminated with $\mathrm{Pb}, \mathrm{Ni}$ and $\mathrm{Cd}$. These contaminants were brought to the subsurface layers of the soil at relatively high concentrations. Total and DTPA-extractable contents of $\mathrm{Pb}$ and $\mathrm{Ni}$ in the top surface soil decreased with increasing the distance from the high way on both sides of the road. Moreover, concentrations of these metals in the cabbage parts were significantly correlated with their total and DTPA-extractable contents. However, $\mathrm{Co}$ and $\mathrm{Cd}$ in soils seemed to be not affected by the exhausts of the cars on the highway. Heavy metals decreased in cabbage parts as follows: root $>$ stem $>$ outer leaves $>$ inner leaves $>$ core. Calculated $\mathrm{BAF}$ values for $\mathrm{Pb}, \mathrm{Ni}$ and $\mathrm{Co}$ were very low indicating that cabbage might be an excluder for these metals whereas, their transfer from roots to shoots (transfer factor, Ts) were high. Heavy metal concentrations in citrus decreased as leaves $>$ flavedo $>$ albedo $>$ segments. Generally, concentrations of heavy metals in plants particularly $\mathrm{Pb}$ exceeded the permissible limits.
\end{abstract}

Keywords: Automobile exhausts, Heavy metals, Cairo-Alexandria agricultural highway, Cabbage, Citrus trees.

Pollution is the introduction of contaminants into the natural environment that causes adverse change in ecosystem (Lone et al., 2008) and affect soil, plant, ground water and consequently human health (Möller et al., 2005 and Abdelhafez et al., 2014). Three factors determine the severity of a pollutant: its chemical nature, concentration and the persistence (Miller, 2007). Heavy metals are considered one of these pollutants which are found in soil crust naturally as trace elements by weathering of geological materials (Shea, 1996). These metal ions persist in soil and don't undergo biodegradation (Tangahu et al., 2011). Heavy metal spread widely as a result of anthropogenic activities and industrial revolution. Heavy metals concentrations which exceed the permissible limits cause a serious ecological disaster (Akguc et al., 2008; Huseyinova et al., 2009), and cause severe health deterioration particularly to children (WHO, 1995). Heavy metals translocation via food chain and accumulation in human bodies cause potential health hazards and death.

Automobile exhausts are considered the main source of air pollution with heavy metals (Karlsson, 2004) particularly pollution with lead $(\mathrm{Pb})$ in areas surrounding the highway due to adding organic lead compounds such as tetra ethyl lead and tetra methyl lead to petrol (Awofoluor, 2004). Also, $\mathrm{Ni}$ is found in vehicle emissions (Thomaidis et al., 2003). The airborne heavy metals and other suspended pollutants are precipitated on soils surrounding highways and plants grown thereon (Hansmann and Köpple, 2000). It is worthy to mention that there is a relationship between human activities and the gradients of heavy metal 
concentrations (MartínezGarcía et al., 2001). Cadmium was found in fine soil particles (street dust) (Pagotto et al., 2001 and Sezgin et al., 2004) and this concentration decreased with increasing distance from the highway (Grigalavičienè et al., 2005 and Nabulo et al., 2006). The effect of highway traffic on contaminating the nearby lands with Co seemed to be negligible or insignificant. Soil particles contaminated with cobalt can be dispersed by wind (WHO, 2006). Such suspended particles might precipitate at high concentrations in soils near highway and, to a lower extent, at lower concentrations away from the highway. There are several forms of heavy metals in soils, a soluble form which is available to be absorbed by plants as well as complexed forms consist of heavy metals combined with organic or in organic compounds (Singh et al., 2012 and Radulescu et al., 2013). Heavy metals translocation from soil solution through roots to other plant parts and accumulate in high concentrations causing a serious risk on human health when these plants are consumed (Ashworth and Alloway, 2004). Some plants can absorb these soluble heavy metals and accumulate them in their organs at high levels $\left(1-50 \mathrm{~g} \mathrm{~kg}^{-1}\right.$ dry weight), these plants are called hyper-accumulator plants (Baker and Brooks, 1989). Cabbage is considered one of these hyper accumulators for some heavy metals which can be absorbed and accumulate in high levels in its edible parts (Radulescu et al., 2013).
The main target of this study is to evaluate levels of some heavy metals in the surface ( 0 $15 \mathrm{~cm})$ and subsurface $(1540-\mathrm{cm})$ soils nearby the highway of Cairo-Alexandria agricultural road because most of the previous studied were conducted on the surface layer only. Also, studying the implications of presence of such metal ions on both shallow and relatively deep rooted plants grown there on would be a matter of concern in this study. Fulfilling such targets would be helpful to evaluate how far the concentrations of the heavy metals in edible plant parts are from the permissible limits so that we may draw a suitable plan for selecting shallow and/or deep rooted plants more appropriate for cultivation in such contaminated soils.

\section{Materials and Methods}

Site description and sampling

For studying the effect of vehicle exhausts on contamination of soils with heavy metals, different locations were selected at Toukh, Qualubia governorate, Egypt nearby and away from CairoAlexandria agricultural highway. Seven locations were sampled from soils at 50 meters intervals starting from the immediate vicinity of the road up to a distance of $300 \mathrm{~m}$ from both the right and left sides of the road at two depths, i.e. the top surface soil $(0-15 \mathrm{~cm})$ and sub-surface soil (15 $-40 \mathrm{~cm})$. Chemical and physical characteristics of the investigated soils are presented in Table 1.

TABLE 1. Physical and chemical characteristics of soil samples

\begin{tabular}{|c|c|c|c|c|}
\hline Soil Characteristics & \multicolumn{2}{|c|}{ Soil 1} & \multicolumn{2}{|c|}{ Soil 2} \\
\hline \multicolumn{5}{|l|}{ Particle size distribution ( $\%)$} \\
\hline Sand & $23.2 \pm 3.4$ & $22.2 \pm 3.2$ & $25.8 \pm 4.2$ & $22.0 \pm 4.1$ \\
\hline Clay & $61.5 \pm 6.9$ & $64.2 \pm 1.8$ & $53.0 \pm 8.6$ & $55.1 \pm 6.4$ \\
\hline Textural class* & \multicolumn{2}{|c|}{ Heavy clay } & \multicolumn{2}{|c|}{ Heavy clay } \\
\hline Calcium carbonate $\left(\mathrm{g} \mathrm{kg}^{-1}\right)$ & $57.6 \pm 9.5$ & $46.9 \pm 1.6$ & $68.9 \pm 9.1$ & $45.1 \pm 4.1$ \\
\hline Organic matter $\left(\mathrm{g} \mathrm{kg}^{-1}\right)$ & $27.2 \pm 3.1$ & $21.5 \pm 0.3$ & $39.1 \pm 2.4$ & $21.1 \pm 0.9$ \\
\hline
\end{tabular}

Egypt. J. Soil Sci. 57, No. 2 ( 2017 ) 


\section{oil analysis}

Heavy metals $(\mathrm{Pb}, \mathrm{Ni}, \mathrm{Co}, \mathrm{Cd})$ were extracted from the investigated soil samples by DTPA (Lindsay and Norvell, 1978) and corresponding soil samples were digested using a tri-acid mixture to determine total amounts of these heavy metals according to Sahrawat et al. (2002). Extractable $\mathrm{Pb}, \mathrm{Ni}, \mathrm{Co}$, and $\mathrm{Cd}$ as well as their total contents in soil were determined by Atomic absorption spectrophotometer 210VGP.

\section{Plant analysis}

Cabbage plants (Brassica oleracea var. capitata) were sampled from the right side of the road, separated into leaves, stems and roots. Fruits and leaves of citrus plants (Citrus sinensis) were sampled from the left side of the road and fruits were separated into their parts (flavedo, albedo, and orange segment). The sampled plants were rinsed thoroughly with distilled water, separated as mentioned before, dried at $70{ }^{\circ} \mathrm{C}$ for $72 \mathrm{~h}$, crushed and digested using an acid mixture of concentrated $\mathrm{H}_{2} \mathrm{SO}_{4} / \mathrm{HClO}_{4}$ (Grimshaw, 1987). The studied heavy metals i.e. $\mathrm{Pb}, \mathrm{Ni}, \mathrm{Co}$ and $\mathrm{Cd}$ were determined by Atomic absorption spectrophotometer 210VGP.

Bioaccumulation factor (BAF) was calculated in stem $\left(\mathrm{BAF}_{\text {stem }}\right)$, outer leaves $\left(\mathrm{BAF}_{\text {outer leaves }}\right)$, inner leaves $\left(\mathrm{BAF}_{\text {innerleaves }}\right)$ and core $\left(\mathrm{BAF}_{\text {core }}\right)$ according to Uchida et al. (2007) as the ratio between the concentration of heavy metal in the investigated plant part and its total content in soil. Translocation factor (Ts), the ratio between the concentration of heavy metal in the investigated areal plant part and its corresponding content in root, was calculated according to Abbas and Abdelhafez (2013). Graphs were plotted using Sigma Plot 10 program.

\section{Results and Discussion \\ Heavy metals in soil}

Figure 1 shows that the total and DTPAextractable contents of $\mathrm{Pb}$ in the surface soil (015$\mathrm{cm}$ ) decreased with increasing the distance from the highway on both sides of the road. Such a result indicates that the exhausts of the cars that contain leaded petrol (UNEP, 2000) might contribute to the pollution of these soils. Average values of total $\mathrm{Pb}$ ranged from 135 to $253 \mathrm{mg} \mathrm{kg}^{-1}$ in the topsoil layer; whereas, the average $\mathrm{Pb}$ content in soils according to WHO (1995) ranges between 0.5 and $10 \mathrm{mgkg}^{-1}$. According to Kabata-Pendias (1995), $\mathrm{Pb}$ level in the investigated soils is considered exceeding the acceptable concentrations proposed by UK, Austria and Poland $\left(100 \mathrm{mgkg}^{-1}\right)$; however these concentrations are still below the Canadian $\left(200 \mathrm{mgkg}^{-1}\right)$, Japanese $\left(400 \mathrm{mgkg}^{-1}\right)$ and German acceptable levels $\left(500 \mathrm{mgkg}^{-1}\right)$. Thus, it can be deduced that also lead is exceeding the permissible limits according to some countries and within the permissible ones in some others, yet we have to consider the least concentration level of Poland for fearing of some expected implications on the plants grown on such contaminated soils and consequently the harmful effect expected to be on the plants grown thereon

Concerning total $\mathrm{Ni}$ content in soils, the obtained values exceeded all the above mentioned countries permissible levels $\left(100 \mathrm{mgkg}^{-1}\right)$ in soil. Contamination of soils with Ni might result from different anthropogenic sources such as vehicle emissions beside of fertilizers and organic manure (Kabata-Pendias and Pendias, 1999; Salt et al., 1999; Alloway, 2013). Accordingly, we can consider that the investigated soils on both the sides of Alexandria-Cairo agricultural road are contaminated to different degrees with both $\mathrm{Pb}$ and $\mathrm{Ni}$. Soils at the right side of the road contained relatively lower concentrations of $\mathrm{Pb}$ and $\mathrm{Ni}$ than the ones at the left side of the road. Direction of the wind might account for such variations.

On the other hand, the distribution patterns of total forms of $\mathrm{Co}$ and $\mathrm{Cd}$ in soils indicate that the soil contamination with these elements seemed not to be affected by the exhausts of the cars on the highway (Figs 3 and 4). Some other factors might contribute in contamination of these soils with Co and Cd e.g. fertilizers (Abdelhafez et al., 2012). Cobalt concentrations in soils of study did not exceed the permissible level i.e. $50 \mathrm{mgkg}^{-1}$ according to Kabata-Pendias (1995). Although, soil cadmium exceeded the permissible levels of the UK (1 mgkg-1), Germany $\left(2 \mathrm{mgkg}^{-1}\right)$ and Poland $\left(3 \mathrm{mgkg}^{-1}\right)$; however, these values were still below the permissible level of Canada ( 8 $\mathrm{mgkg}^{-1}$ ). Average concentrations of total cobalt in soils of Egypt ranged between 16.5 - $26.8 \mathrm{mgkg}^{-1}$ (Nasseem and Abdalla, 2003). Accordingly, these soils are considered contaminated with $\mathrm{Cd}$. The main sources of $\mathrm{Cd}$ pollution in most agricultural lands are atmospheric depositions particularly through fly ash during incineration and mineral fertilization (Alloway and Steinnes, 1999; Eckel et al., 2005) as well as fossil fuel combustion (Kabata-Pendias and Mukherjee, 2007). 
Migration of $\mathrm{Pb}$ and $\mathrm{Ni}$ to the subsurface layer (1540- $\mathrm{cm})$ was higher in soils at the right side of the road than at the left ones (Figs 1 and 2). It is well known that $\mathrm{Pb}$ and $\mathrm{Ni}$ strongly adsorbed by soil particles and thus are considered immobile metals (Wuana \& Okieimen, 2011 and Young, 2013). Generally $\mathrm{Pb}$ mobilization through soil horizons is very low but acidity and formation of $\mathrm{Pb}$ - organo complexes play a vital role in increasing $\mathrm{Pb}$ solubility and mobilization (KabataPendias and Sadurski, 2004). Therefore, their migration to the subsurface layers is expected to be limited. Likewise, nickel mobility in soils is very slight (Zhang et al., 2004). However, regular
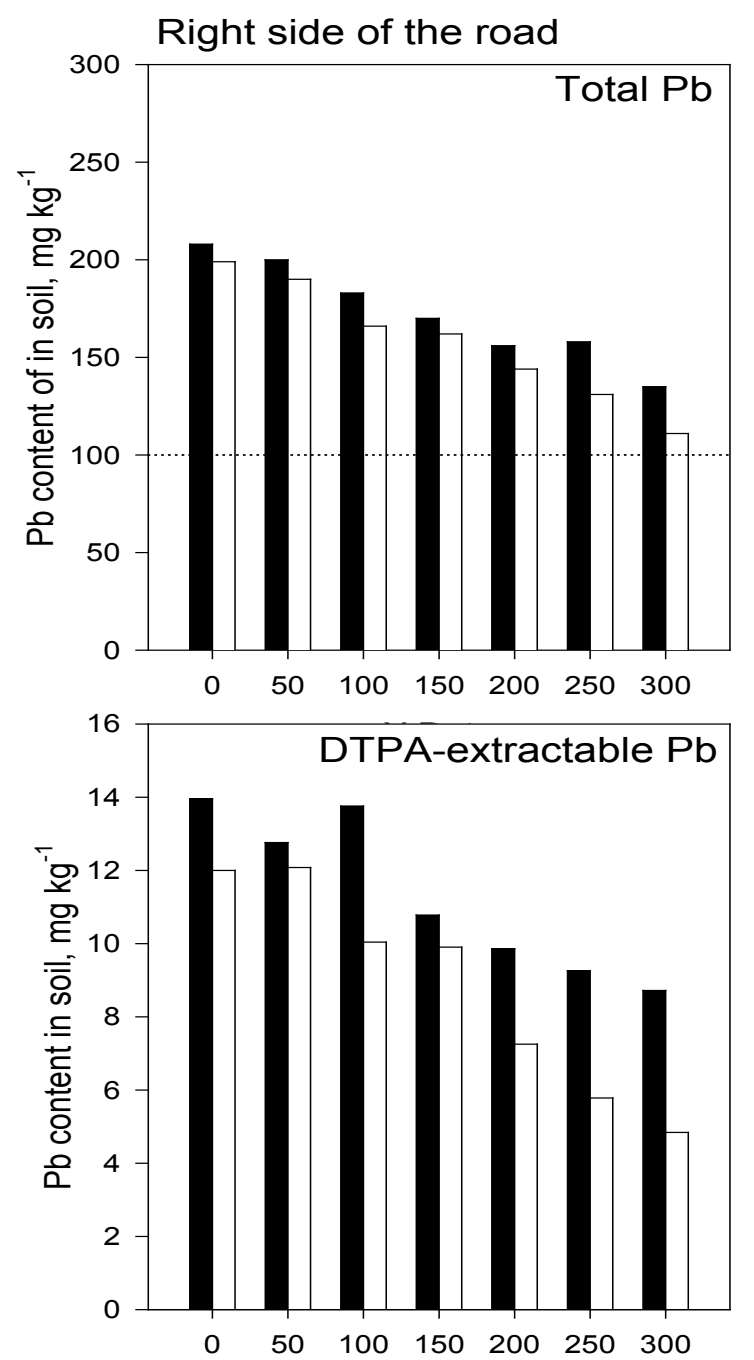

Distance from highway, meter agricultural practices carried out on soils of the right side of the road before cultivating crops and vegetables ,e.g. incorporation of the surface with the subsurface layers through the plowing process might account partially for increasing concentrations of $\mathrm{Pb}$ and $\mathrm{Ni}$ in the subsurface layer to be slightly lower than the corresponding concentrations in the surface one. On the other hand, soils which are cultivated with citrus trees, found at the right side of the road, need somewhat limited agricultural practices which don't involve incorporation process and therefore, are still characterized by higher contents of both lead and cobalt in the surface layers than the deeper ones.
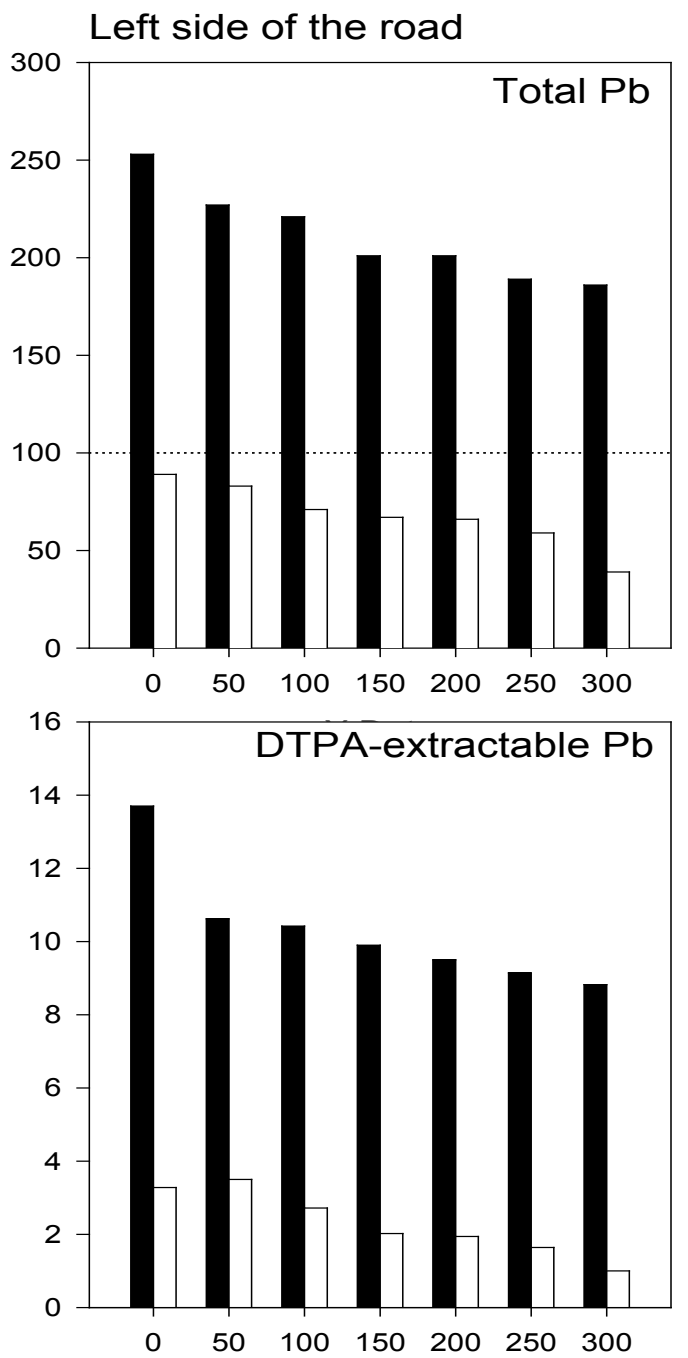

Distance from highway, meter

Surface layer $(0-15 \mathrm{~cm})$

Subsurface layer $(15-40 \mathrm{~cm})$

Fig 1. Total and DTPA-extractable Pb of the investigated soil (Reference maximum acceptable level (MAC) was shown by the dot-line)

Egypt. J. Soil Sci. 57, No. 2 ( 2017 ) 

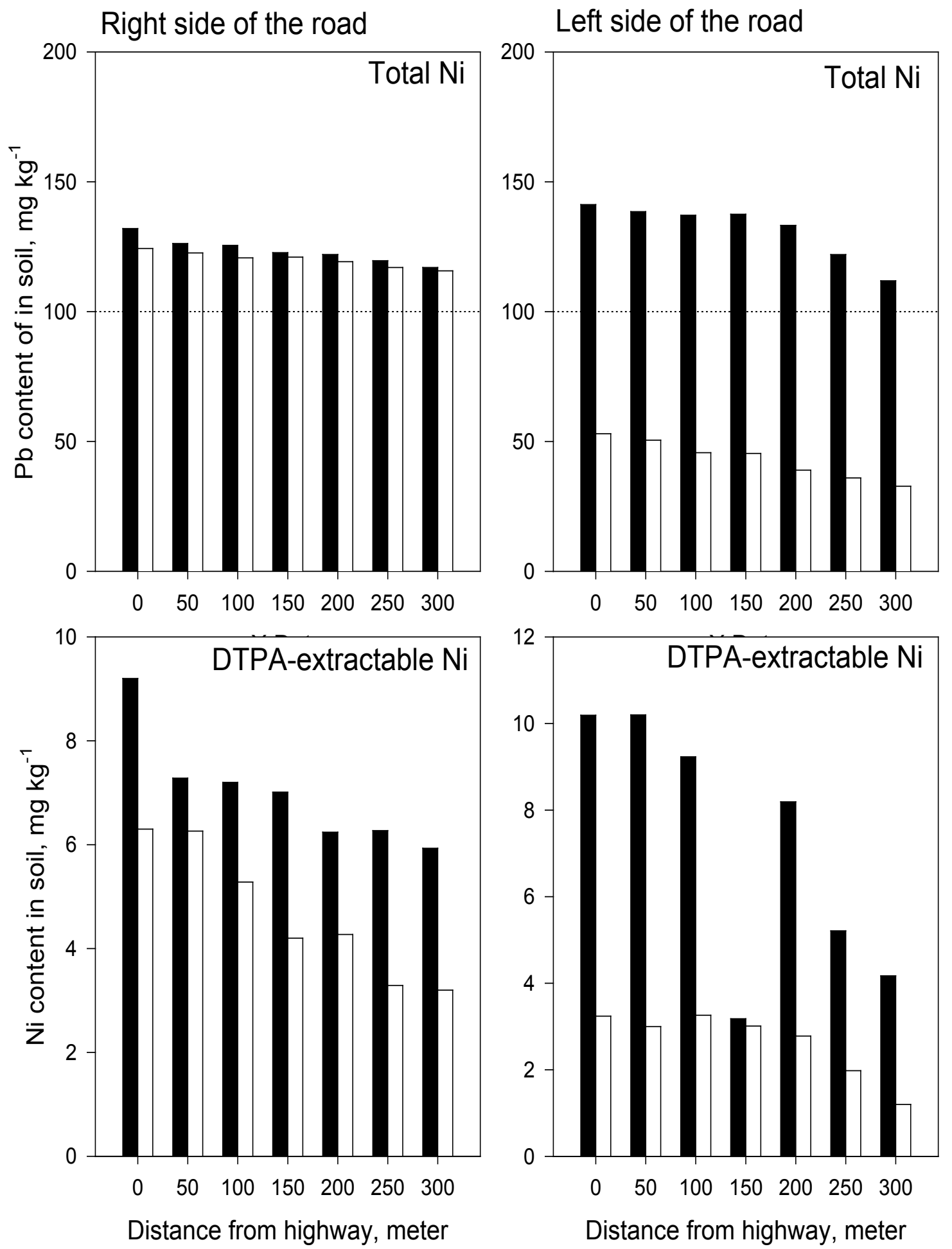

Distance from highway, meter

Surface layer $(0-15 \mathrm{~cm})$

Subsurface layer $(15-40 \mathrm{~cm})$

Fig. 2. Total and DTPA-extractable Ni of the investigated soil (Reference maximum acceptable level (MAC) was shown by the dot-line) 

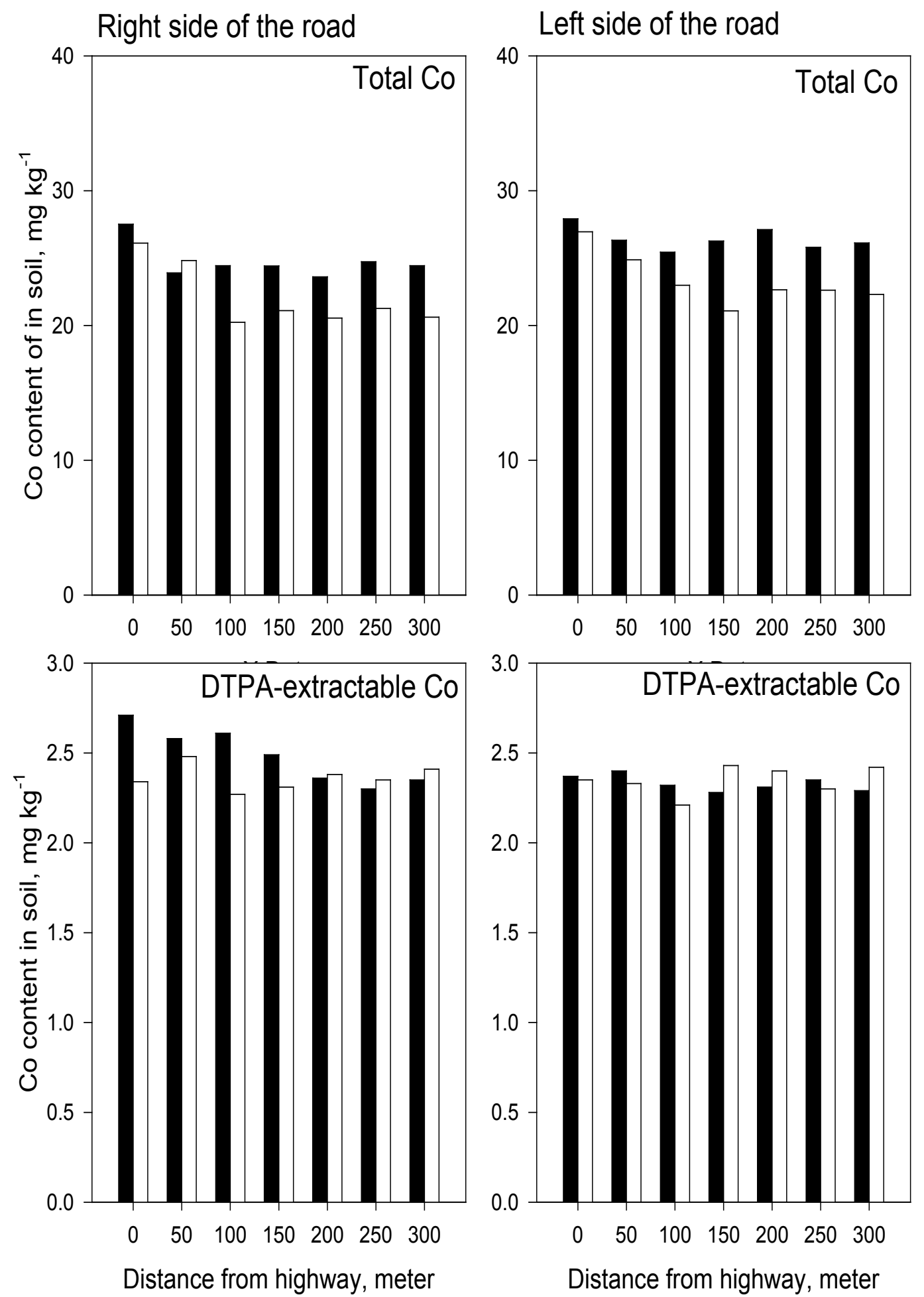

Surface layer $(0-15 \mathrm{~cm})$

Subsurface layer $(15-40 \mathrm{~cm})$

Fig. 3. Total and DTPA-extractable Co of the investigated soil. 

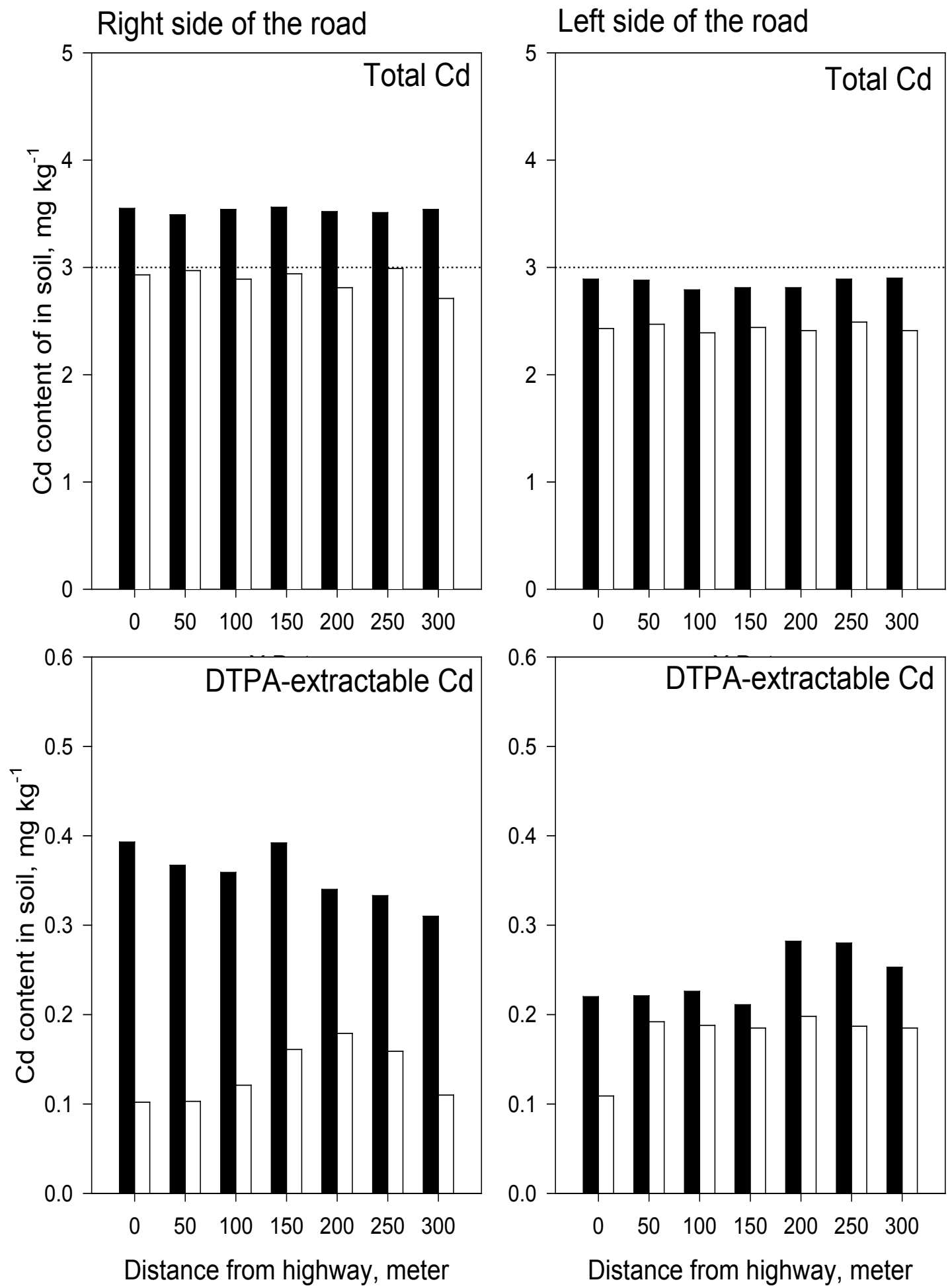

Distance from highway, meter

Surface layer $(0-15 \mathrm{~cm})$

Subsurface layer $(15-40 \mathrm{~cm})$

Fig. 4. Total and DTPA-extractable Cd of the investigated soil (Reference maximum acceptable level (MAC) was shown by the dot-line) 
Total contents of $\mathrm{Cd}$ and $\mathrm{Co}$ in the subsurface layers of soil seemed to be almost slightly lower than their corresponding ones in the surface layer on both sides of the highway.

DTPA extractable forms of the investigated heavy metals represented only $6 \%$ of the total contents of $\mathrm{Pb}$, about $7 \%$ for $\mathrm{Ni}$, and around $10 \%$ of each of $\mathrm{Co}$ and $\mathrm{Cd}$. This probably indicates that only small fractions of these heavy metals could be available to plant.

However, to what extent could these fractions accumulate in different parts of the grown plants, was the question that the current research tried to answer. It is worthy to mention that the transfer of heavy metals from soil to plant is an important criterion in food safety issues (Jolly et al., 2013).

Heavy metals in cabbage plants grown on the right side of the highway

Lead in cabbage

Figure 5 reveals that concentrations of $\mathrm{Pb}$
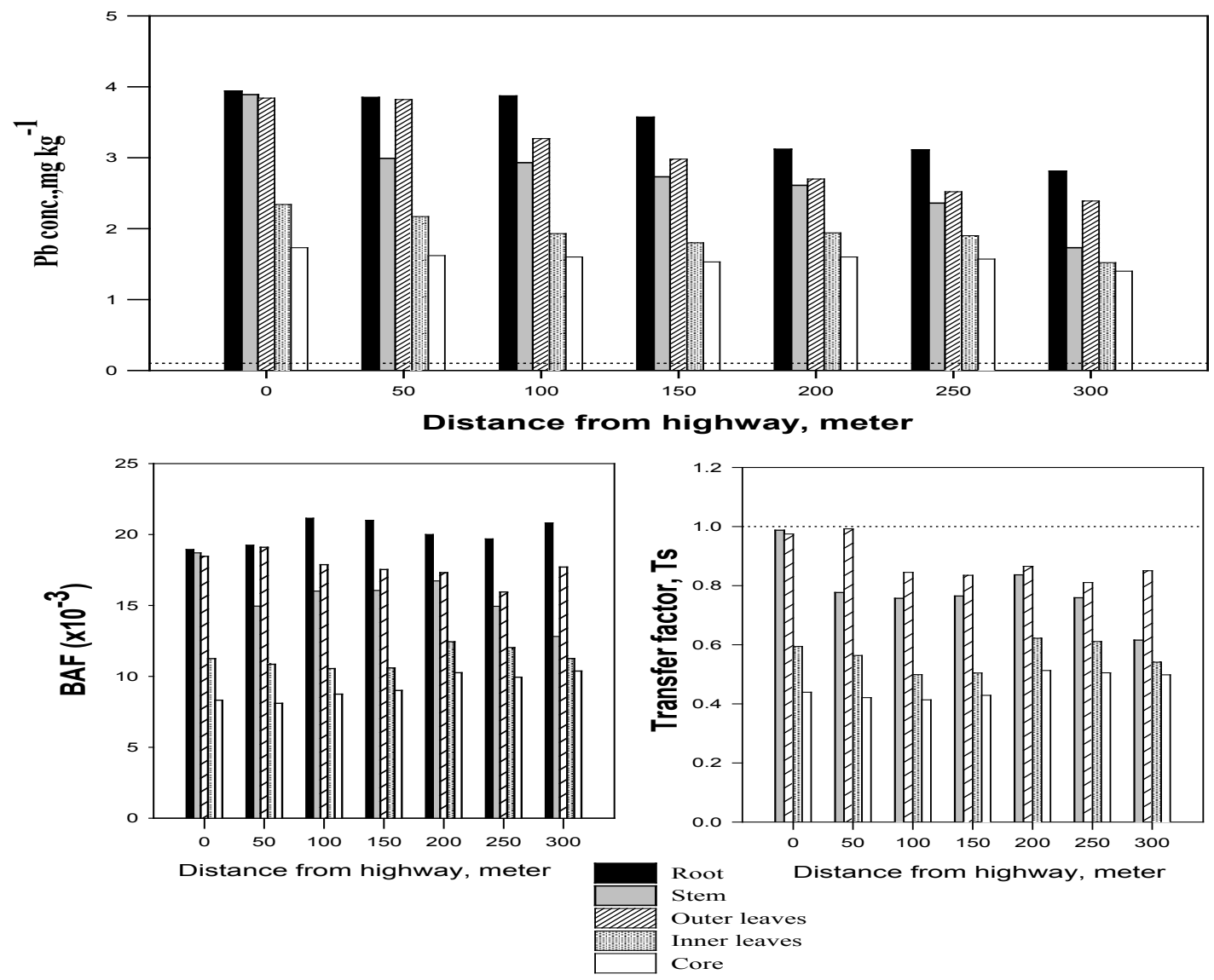

Fig. 5. Lead concentrations within the different parts of cabbage plants and the calculated biological accumulation factor (BAF) and transfer factors (Ts) as affected by the distance from the highway

Egypt. J. Soil Sci. 57, No. 2 ( 2017 ) within the edible parts of cabbage were much higher than the codex maximum level in leafy vegetables which is $0.1 \mathrm{mgkg}^{-1}$ (IADSA, 1995) and $0.3 \mathrm{mgkg}^{-1}$ for brassica (FAO and WHO, 2001). Such concentrations are at least 15 times higher than the permissible level. The threshold levels of toxicity in cabbage leaves are 150350$\mathrm{mgkg}^{-1}$ (Sinha et al., 2006). Thus, cabbage can accumulate high concentrations of $\mathrm{Pb}$ in heads without showing $\mathrm{Pb}$ toxicity symptoms. Moreover, cabbage could accumulate up to $5010 \mathrm{mg} \mathrm{Pb} \mathrm{kg}^{-1}$ from soil contaminated with $\mathrm{Pb}$ in presence of EDTA (Shen et al., 2002). Lead concentrations in the plant parts decreased, generally, in the following sequence: root $>$ stem $>$ outer leaves $>$ inner leaves $>$ core. This result confirms that inner leaves of cabbage and its core, generally, contain lower $\mathrm{Pb}$ concentrations and are considered more safe for ingestion than the outer leaves. 
Lead contents within the different plant parts significantly correlated with total and DTPAextractable contents in soil (Table 2). Accordingly, soil contamination by lead is thought to be the main reason of $\mathrm{Pb}$ uptake by cabbage plants and its bio-concentration within the different plant parts. Areal uptake of $\mathrm{Pb}$ might be considered of less importance in this concern. The relation between $\mathrm{Pb}$ contents in the different plant parts and its total content in soil was calculated as biological accumulation factor (BAF) and plotted graphically in Figure 5. The calculated values were very low and this indicates that cabbage is probably not a $\mathrm{Pb}$-accumulator plant, and on the other hand, it might be considered an excluder. Transfer of $\mathrm{Pb}$ from roots to shoots (transfer factor, Ts) was high (Ts of outer leaves ranged between 0.81 and 0.99 ), and relatively lower in the inner leaves (Ts of inner leaves ranged between 0.50 and 0.62 ) while the corresponding values of the core were the least (Ts of core ranged between 0.41 and 0.51). Sekara et al. (2005) found also high translocation of $\mathrm{Pb}$ in white cabbage from root to rosette leaves

Nickel in cabbage

Results shown in Fig 6 illustrate the distribution pattern of $\mathrm{Ni}$ within the different cabbage parts. Unlike $\mathrm{Pb}, \mathrm{Ni}$ accumulated in relatively low concentrations in roots while sensible concentrations were translocated to the areal parts of the cabbage plants especially within the cores (high values of the translocation factor exceeding "one"). Moreover, inner leaves contained relatively higher $\mathrm{Ni}$ concentrations than the outer leaves. Such a result probably shows that cabbage probably needs $\mathrm{Ni}$ as a beneficial element (Welch \& Shuman, 1995 \& Yusuf et al., 2011) since Ni is highly phloem-mobile (Page and Feller, 2015). Nickel concentrations exceed the permissible level (i.e. $0.20 \mathrm{mgkg}^{-1}$ ) in some of the cabbage plant parts according to the permissible levels outlined by FAO and WHO (2001).

Although, Ni concentrations within the different plant parts were significantly correlated with the total and DTPA extractable Ni in soil (Table 2); yet, very low concentrations of Ni were taken by plant roots (BAF values were very low) and this might indicate that cabbage is not a Niaccumulator plant. Also, soil Ca might minimize $\mathrm{Ni}$ uptake by plant roots thus reduces its toxicity (Chaney et al., 2008 and Yusuf et al., 2011).

TABLE 2. Correlation coefficient values of heavy metal contents within the different cabbage parts as affected by total and available contents in soil

\begin{tabular}{|c|c|c|c|c|c|c|c|c|c|c|c|c|}
\hline & $\begin{array}{c}\text { DTPA- } \\
\text { extractable }\end{array}$ & Root & stem & $\begin{array}{l}\text { Outer } \\
\text { leaves }\end{array}$ & $\begin{array}{l}\text { Inner } \\
\text { leaves }\end{array}$ & Core & $\begin{array}{c}\text { DTPA- } \\
\text { extractable }\end{array}$ & root & stem & Outer leaves & $\begin{array}{l}\text { Inner } \\
\text { leaves }\end{array}$ & core \\
\hline & \multicolumn{6}{|c|}{ Lead $(\mathrm{Pb})$} & \multicolumn{6}{|c|}{ Nickel (Ni) } \\
\hline Total & $0.922^{* *}$ & $0.953^{* *}$ & $0.931^{* *}$ & $0.977^{* * *}$ & $0.913^{* *}$ & $0.859 *$ & $0.956^{* *}$ & $0.937 * *$ & $0.913 * *$ & $0.800^{*}$ & $0.891^{*}$ & $0.801 *$ \\
\hline $\begin{array}{l}\text { DTPA- } \\
\text { extractable }\end{array}$ & & $0.963^{* * *}$ & $0.868 *$ & $0.917 * *$ & $0.765^{*}$ & $0.758^{*}$ & & $0.847^{*}$ & $0.775^{*}$ & 0.681 & $0.789^{*}$ & 0.720 \\
\hline Root & & & $0.874 *$ & 0.931 ** & $0.775^{*}$ & $0.754^{*}$ & & & $0.938 * *$ & 0.711 & $0.809^{*}$ & 0.659 \\
\hline Stem & & & & $0.878^{* *}$ & $0.925 * *$ & $0.937 * *$ & & & & $0.894 * *$ & $0.929 * *$ & $0.838^{*}$ \\
\hline Outer leaves & & & & & $0.859^{*}$ & $0.773^{*}$ & & & & & $0.972 * * *$ & $0.982^{* * *}$ \\
\hline Inner leaves & Cobalt (Co) & & & & & $0.970 * * *$ & Cadmium (C & & & & & $0.962 * *$ \\
\hline $\begin{array}{l}\text { Total } \\
\text { DTPA- } \\
\text { extractable }\end{array}$ & 0.576 & $\begin{array}{l}0.044 \\
-0.562\end{array}$ & $\begin{array}{l}0.136 \\
-0.319\end{array}$ & $\begin{array}{l}0.486 \\
0.548\end{array}$ & $\begin{array}{l}0.435 \\
0.120\end{array}$ & $\begin{array}{l}0.003 \\
-0.63\end{array}$ & 0.321 & $\begin{array}{l}0.162 \\
-0.559\end{array}$ & $\begin{array}{l}0.491 \\
-0.309\end{array}$ & $\begin{array}{l}-0.18 \\
0.739\end{array}$ & $\begin{array}{l}0.414 \\
0.018\end{array}$ & $\begin{array}{l}0.487 \\
0.685\end{array}$ \\
\hline Root & & & 0.173 & -0.0343 & 0.069 & 0.280 & & & 0.376 & -0.355 & 0.591 & -0.018 \\
\hline Stem & & & & -0.168 & 0.688 & 0.553 & & & & -0.156 & 0.505 & 0.083 \\
\hline Outer leaves & & & & & 0.342 & 0.089 & & & & & 0.409 & 0.382 \\
\hline Inner leaves & & & & & & 0.335 & & & & & & 0.227 \\
\hline
\end{tabular}

Note: ${ }^{*} \mathrm{p}<.05 ;{ }^{* *} \mathrm{p}<.01 ; * * * \mathrm{p}<.001$ 

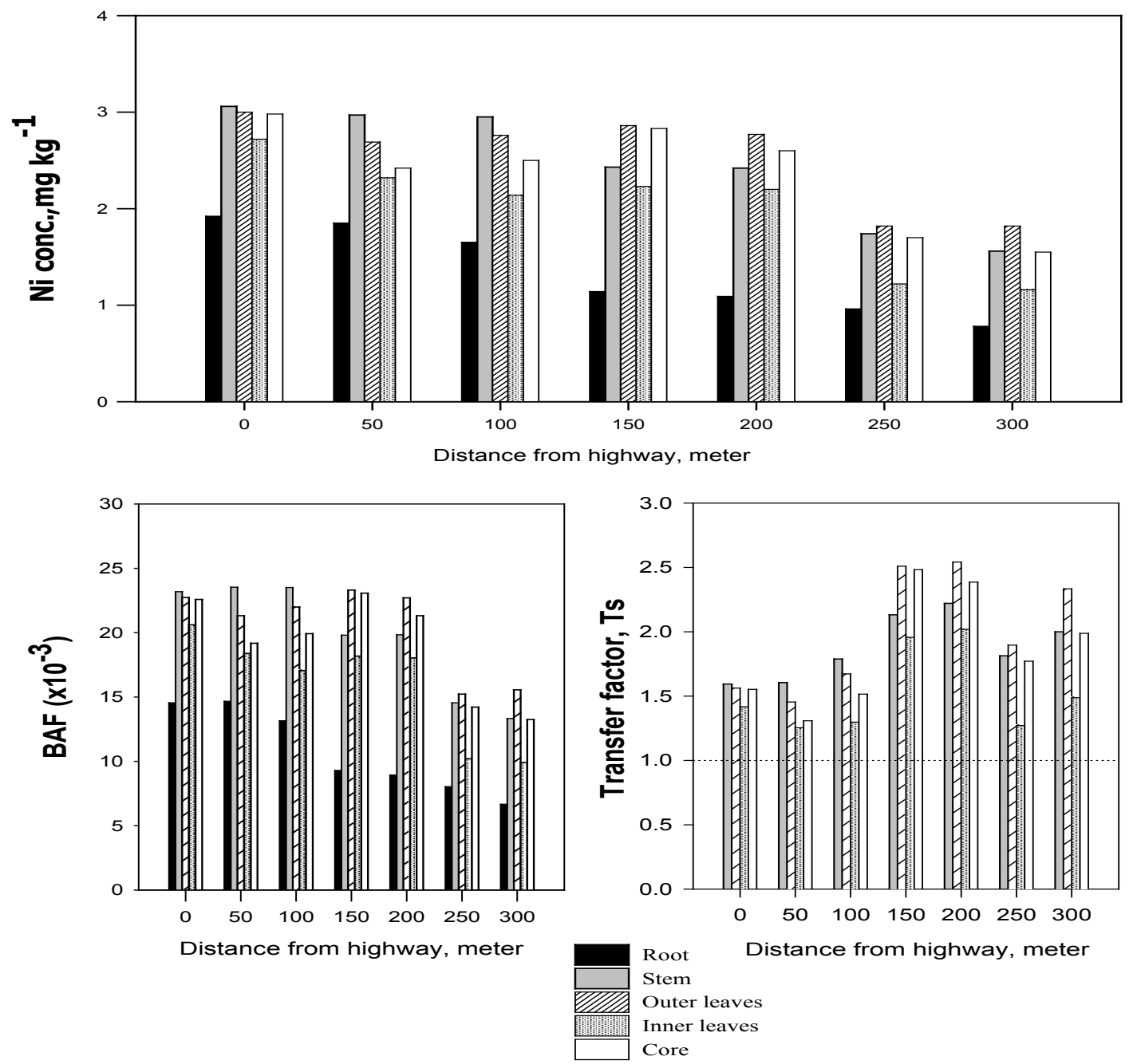

Fig. 6. Nickel concentrations within the different parts of cabbage plant (A) and the calculated biological accumulation factor (BAF) and transfer factors (Ts) as affected by the distance from the highway

\section{Cobalt in cabbage}

Cobalt concentrations within the different plant parts were relatively low compared with the corresponding concentrations of $\mathrm{Pb}$ and Ni (Fig. 7). Although, roots retain relatively high concentrations of $\mathrm{Co}$; yet considerable concentrations of Co were translocated to the areal parts of cabbage plants. Probably, Co is a beneficial element (Marschner, 1995; Bakkaus et al., 2005). The highest concentrations of Co were detected in stems and this probably indicates that Co is a mobile element within the plant. Welch and Shuman (1995) classified Co as an intermediate phloem mobile element. Normal concentrations of cobalt in plants ranges between $0.110-\mathrm{mgkg}^{-1}$ (Bakkaus et al., 2005). Concentration of cobalt in cabbage samples grown nearby the highway did not exceed this normal level
Within the areal parts of cabbage, Co concentrations decreased as follows: outer leaves $>$ inner leaves $>$ core. Low values of the BAF indicates low uptake of Co from soils by cabbage. Translocation of Co from roots to shoots was high (values of the translocation factor exceeded "one" for stem and outer leaves) and, generally, this factor decreased in the following sequence: stem $>$ outer leaves $>$ inner leaves $>$ core.

Correlation analyses indicate that Co concentrations within cabbage parts were neither significantly affected by the total contents in soil nor by the DTPA-extractable form (Table 2). Collins and Kinsela (2011) recorded that soil total content of cobalt has no impact on its uptake by plants. Other soil factors might affect Co availability 
and uptake ,e.g. soil-Mn affect Co availability in soil. Likewise, no significant correlations were detected between Co concentrations and each of the different plant parts.

\section{Cadmium in cabbage}

Cabbage maintains relatively low concentrations of $\mathrm{Cd}$ within its outer and inner leaves and the core (Fig. 8). Higher concentrations of $\mathrm{Cd}$ were detected mainly in roots and stems. Xian (1989) went almost to similar results and recorded higher concentrations of $\mathrm{Cd}$ in roots than in shoots. On the other hand, Sêkara et al. (2005) found higher concentrations of $\mathrm{Cd}$ in leaves of white cabbage than in roots. The codex maximum level of $\mathrm{Cd}$ in leafy vegetables is 0.2 $\mathrm{mgkg}^{-1}$ (IADSA, 1995; FAO and WHO, 2001) and the values of $\mathrm{Cd}$ in edible parts of cabbage obtained from this study were almost double or triple this codex level. This indicates high potential health risk for man feeding on cabbage obtained from the studied locations. Values of the biological accumulation factor were high enough to recommend cabbage as accumulator plants for $\mathrm{Cd}$. Translocation of $\mathrm{Cd}$ to the areal parts was low; therefore, $\mathrm{Cd}$ was probably immobilized through its pathway from roots and hence, its concentration was minimized in the plant leaves and core. In this concern, it was found that Brassica campestris L. is a Cd-accumulating crop which can reduce effective hazard potential of $\mathrm{Cd}$ in soil (Su et al., 2010).

Concentrations of $\mathrm{Cd}$ within the different cabbage parts were not significantly affected by the corresponding total or DTPA-extractable concentrations in soil (Table 2). This might take place through binding $\mathrm{Cd}$ on the pectic sites and hystidyl groups of root cell walls (Nishizono et al., 1989 and Leita et al., 1996). The concentrations of $\mathrm{Cd}$ within the different plant parts did not correlate with each other. Mostly, Cd toxicity stimulated the synthesis of phytochelations and vacuole compartmentalization to detoxify $\mathrm{Cd}$ (Sanità di Toppi and Gabbrielli, 1999). Thus, Cd was immobilized and distributed within the different plant parts through its pathway from roots to the core. Immobilization and partitioning capacity may vary among the different plant parts.

Heavy metals in citrus trees grown on the left side of the highway

In spite of the long pathway of the investigated heavy metals from soil to citrus leaves, concentrations of these metals in leaves were relatively high (Fig. 9). These concentrations were comparable to the concentrations of $\mathrm{Ni}(215-\mathrm{mg}$ $\left.\mathrm{kg}^{-1}\right)$ and Co (0.10.2- $\mathrm{mg} \mathrm{kg}^{-1}$ ) found by Romero et al. (2012) in citrus leaf samples collected from cultivated lands near mines, and lower than the concentrations of $\mathrm{Pb} 0.82 .6-\mathrm{mgkg}^{-1}$ ) and $\mathrm{Cd}$ $\left(<0.01 \mathrm{mgkg}^{-1}\right)$ in our leaf samples. In spite of that, concentrations of $\mathrm{Pb}$ and $\mathrm{Ni}$ were still below toxic levels in citrus leaves mentioned by Aucejo et al. (1997) which were $1020-\mathrm{mgkg}^{-1}$ for $\mathrm{Pb}$ and 50100- $\mathrm{mgkg}^{-1}$ for $\mathrm{Ni}$.

According to FAO and WHO (2001), Pb and $\mathrm{Cd}$ exceeded the permissible limits in fruits i.e. 0.20 and $0.05 \mathrm{mg} \mathrm{kg}^{-1}$, respectively.

Pronounced reductions in concentrations of these metals occurred according to the following sequence: flavedo $>$ albedo $>$ segments. This sequence indicates that citrus plants probably minimized the translocation of heavy metals to the edible parts of the plant to reach less than 8,16 , 19 and $8 \%$ of the corresponding concentrations in leaves for $\mathrm{Pb}, \mathrm{Ni}, \mathrm{Co}$ and $\mathrm{Cd}$, respectively. It is worthy to mention that flavedo and albedo are rich in pectin (Mamma and Christakopoulos, 2014) which can bind heavy metal ions (Kartel et al., 1999). Heavy metals are sorbed on their active functional groups (Marín et al., 2010). Thus, concentration of these metals in citrus segments seemed to be relatively low.

Caselles (1998) conducted his study on a citrus farm next to a busy motor road in Spain and found also that $\mathrm{Pb}$ concentrations decreased in leaves of citrus with increasing the distance from the motor road; however, the concentrations obtained in this study (around $15 \mathrm{mg} \mathrm{Pb} \mathrm{kg}^{-1}$ ) were much higher than the corresponding concentrations obtained therein

Significant correlations were recorded for $\mathrm{Pb}$ and $\mathrm{Ni}$ concentrations among different plant tissues ,i.e. leaves, flavedo, albedo and segments (Table 3). However, no significant correlation was detected among these parts for $\mathrm{Co}$ or $\mathrm{Cd}$. Total and DTPA-extractable contents of $\mathrm{Pb}$ and $\mathrm{Ni}$ in soil had the largest impact on their bio-concentrations in different citrus parts. However, soil $\mathrm{Co}$ and $\mathrm{Ni}$ did not affect significantly their concentrations within the investigated parts of the plant. 
TABLE 3. Correlation coefficient values of heavy metals in citrus as affected by their total and DTPA-extractable contents in soil

\begin{tabular}{|c|c|c|c|c|c|c|c|c|c|c|}
\hline & $\begin{array}{c}\text { DTPA- } \\
\text { extractable }\end{array}$ & Leaf & Flavedo & Albedo & Segment & $\begin{array}{c}\text { DTPA- } \\
\text { extractable }\end{array}$ & Leaf & Flavedo & Albedo & Segment \\
\hline & \multicolumn{5}{|c|}{ Lead $(\mathrm{Pb})$} & \multicolumn{5}{|c|}{ Nickel (Ni) } \\
\hline Total & $0.962 * *$ & $0.926^{*}$ & $0.945^{* *}$ & $0.902 * *$ & $0.926^{* *}$ & 0.722 & $0.959^{* *}$ & $0.920^{* *}$ & $0.981^{* * *}$ & $0.907 * *$ \\
\hline DTPA-extractable & & $0.827 *$ & $0.917 * *$ & $0.869 *$ & $0.927 * *$ & & $0.834 *$ & $0.900^{* *}$ & $0.803^{*}$ & 0.670 \\
\hline Leaf & & & $0.927 * *$ & $0.936^{* *}$ & $0.931^{* *}$ & & & $0.969^{* * *}$ & $0.984^{* * *}$ & $0.888^{* *}$ \\
\hline Flavedo & & & & $0.969^{* *}$ & $0.939^{* *}$ & & & & $0.942^{* *}$ & $0.916^{* *}$ \\
\hline \multirow[t]{2}{*}{ Albedo } & & & & & $0.957^{* *}$ & & & & & $0.891^{*}$ \\
\hline & Cobalt (Co) & & & & & \multicolumn{5}{|l|}{ Cadmium (Cd) } \\
\hline Total & 0.718 & 0.131 & $0.891 * *$ & -0.537 & 0.302 & -0.019 & $0.817^{*}$ & 0.040 & -0.305 & -0.517 \\
\hline DTPA-extractable & & -0.422 & -0.548 & 0.010 & 0.125 & & -0.294 & -0.255 & 0.650 & -0.612 \\
\hline Leaf & & & -0.414 & -0.522 & -0.092 & & & 0.312 & -0.381 & -0.391 \\
\hline Flavedo & & & & 0.562 & -0.342 & & & & 0.087 & -0.238 \\
\hline Albedo & & & & & 0.308 & & & & & -0.385 \\
\hline
\end{tabular}
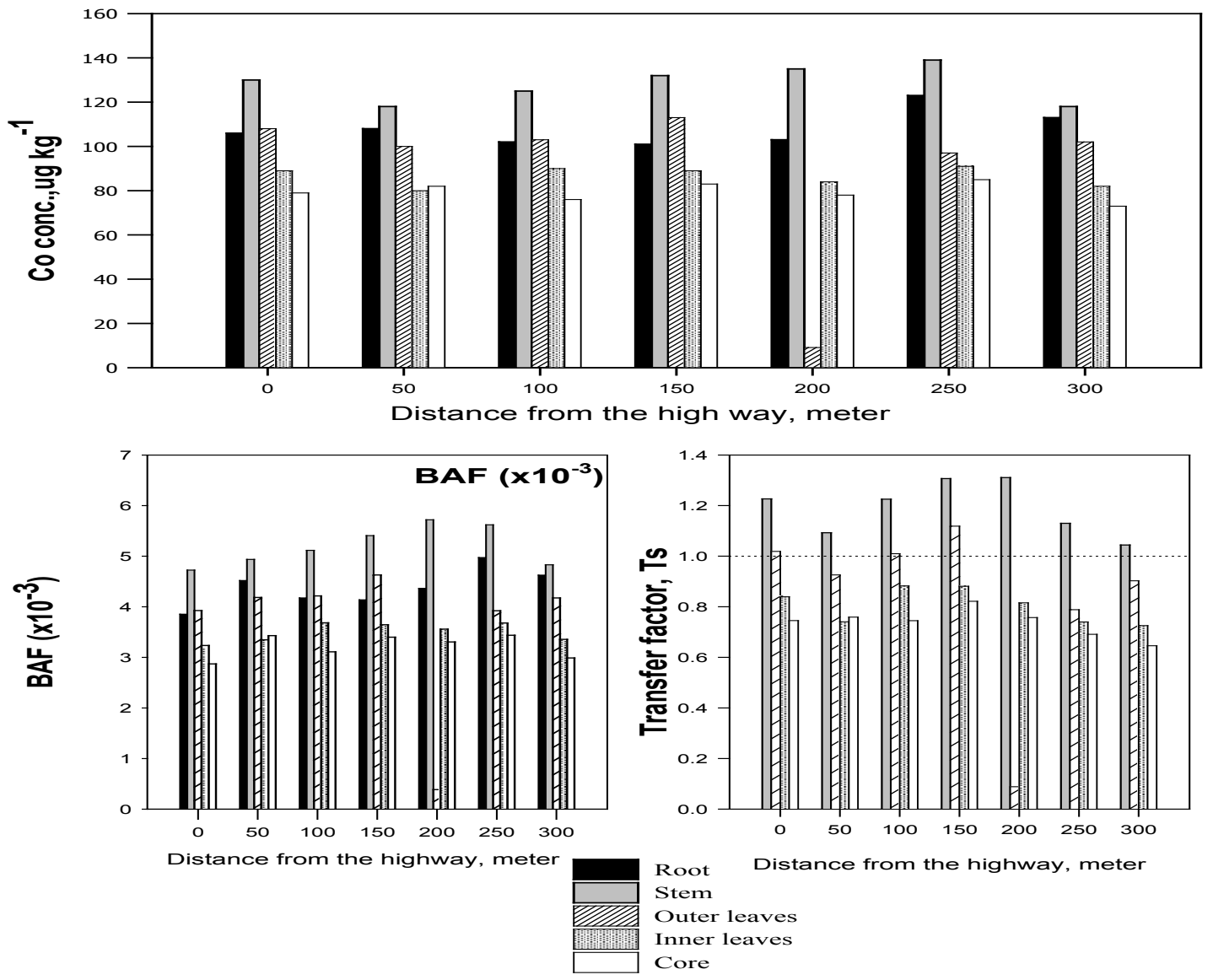

Fig. 7. Cobalt concentrations within the different parts of cabbage plants and the calculated biological accumulation factor (BAF) and transfer factors (Ts) as affected by the distance from the highway.

Egypt. J. Soil Sci. 57, No. 2 ( 2017 ) 


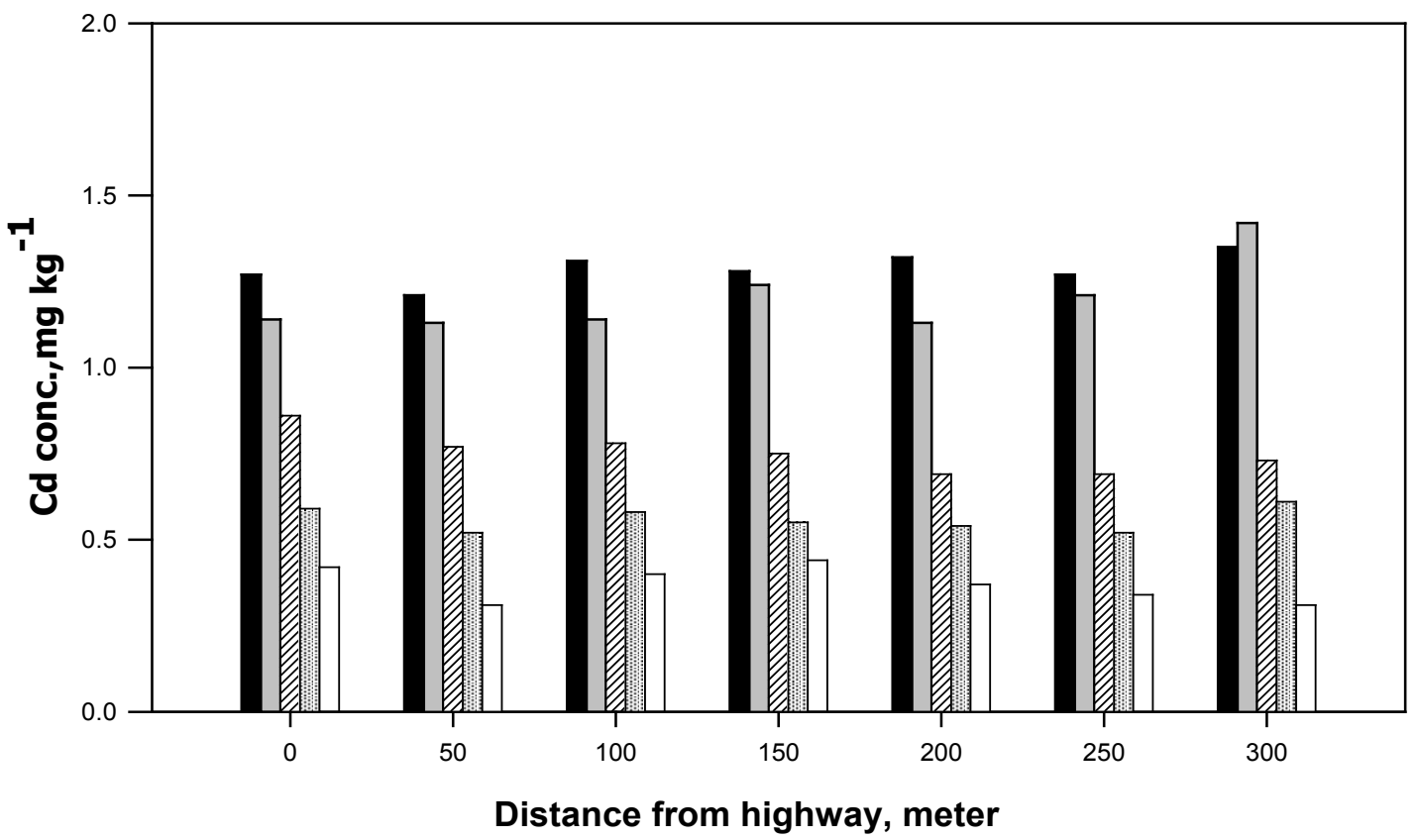

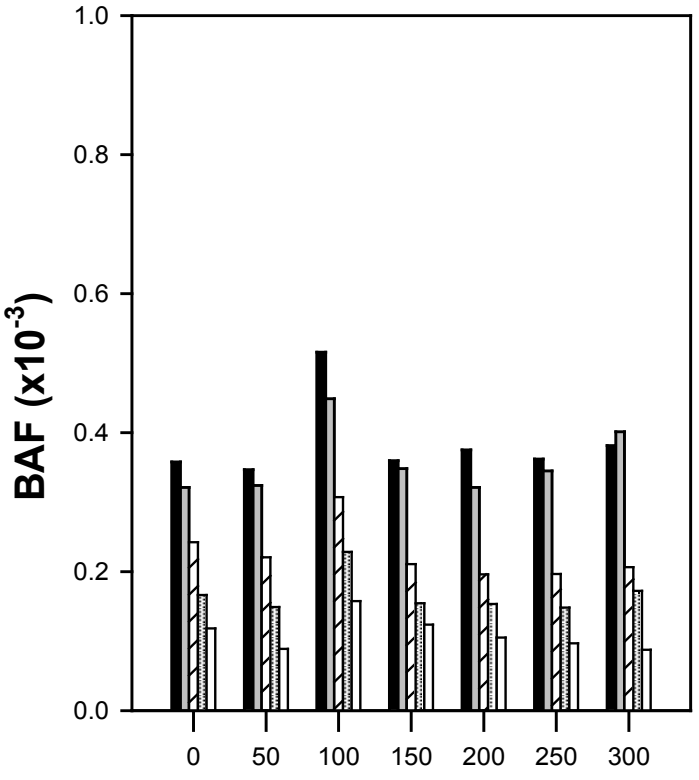

Distance from highway, meter

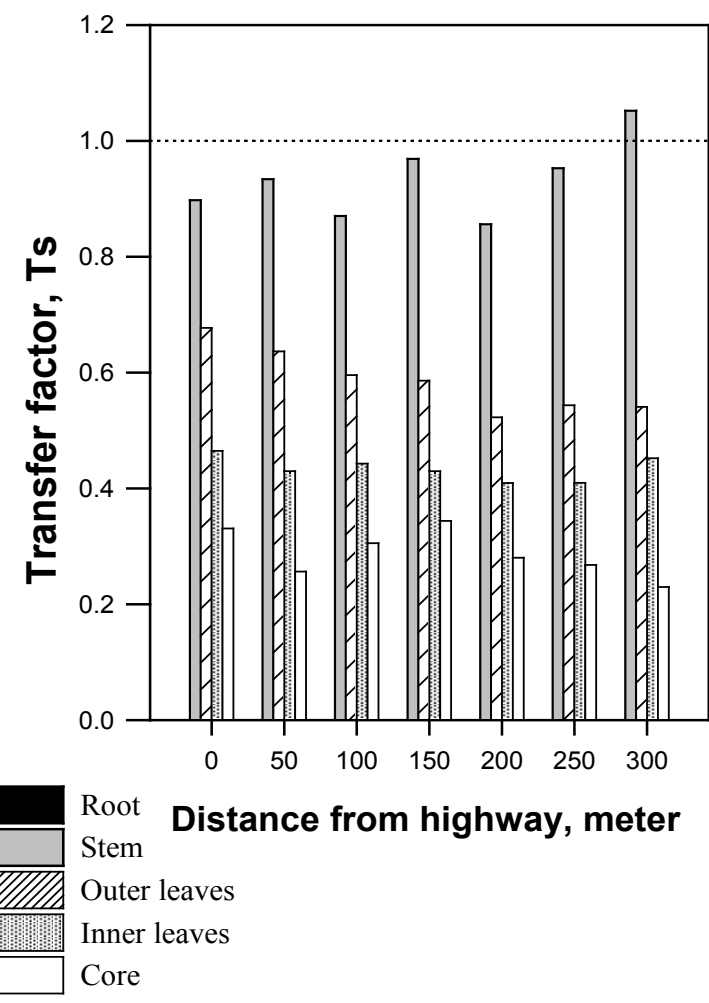

Fig. 8. Cadmium concentrations within the different parts of cabbage plants and the calculated biological accumulation factor (BAF) and transfer factors (Ts) as affected by the distance from the highway 

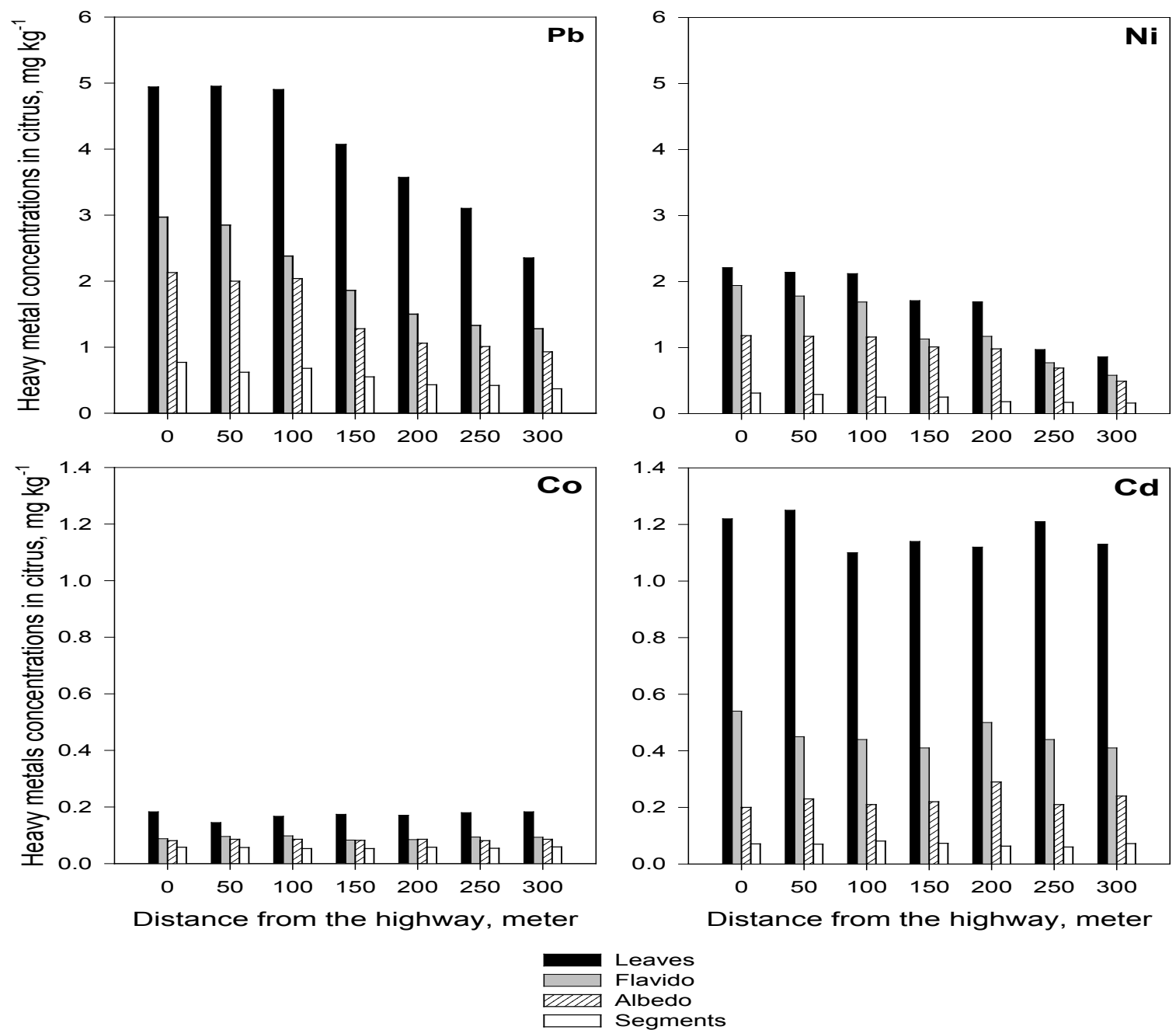

Fig. 9. $\mathrm{Pb}, \mathrm{Ni}, \mathrm{Co}$ and $\mathrm{Cd}$ concentrations within the different parts of citrus plants

\section{Conclusion}

High traffic on the highway near Toukh city increased progressively levels of soil contamination with $\mathrm{Pb}$ and $\mathrm{Ni}$. Agricultural practices, which were carried out regularly on such soils, probably brought the contaminant to the subsurface layers of the soil at relatively high concentrations. These contaminants can't undergo degradation; therefore possess serious potential risk for both human and animal. Although, cabbage is an excluder plant for many heavy metals ,i.e. $\mathrm{Pb}, \mathrm{Co}$ and $\mathrm{Ni}$; however, carelessness in dealings with environmental problems for years had resulted in presence of high and, probably, toxic levels of these contaminants in plant parts. Cabbage accumulates high concentrations of $\mathrm{Cd}$ in its tissues. Accordingly, determining the level of $\mathrm{Cd}$ in the edible parts of cabbage should be considered within the main quality criteria of this product.

Egypt. J. Soil Sci. 57, No. 2 ( 2017 )
In citrus fruits, flavedo and albedo acted as natural defenders that lessened the amounts of heavy metals transferred from leaves to fruit segments. However, increasing levels of soil pollution of heavy metals must be taken into consideration. Concentrations of heavy metals in citrus leaves were relatively high and this might possess serious health problem in the near future.

\section{References}

Abbas, M.H.H. and Abdelhafez, A.A. (2013) Role of EDTA in arsenic mobilization and its uptake by maize grown on an As-polluted soil. Chemosphere 90, 588-594.

Abdelhafez, A.A., Abbas, H.H., Abd - El - Aal, R.S., Kandil, N.K., Li, J. and Mahmoud, W. (2012) Environmental and health impacts of successive mineral fertilization in Egypt. Clean- Soil Air Water 40 (2), 356-363. 
Abdelhafez, A.A., Abbas, M.H.H. and Attia, T.M.S. (2014) Environmental monitoring of heavy-metals status and human health risk assessment in the soil of Sahl El-Hessania area, Egypt. Polish Journal of Environmental Studies, 24 (2), 459-467.

Akgüc, N, Özgiğit, I.I. and Yarci, C. (2008) Pyracantha Coccinea Roem, (Rosaceae) as a bio monitor for $\mathrm{Cd}, \mathrm{Pb}$ and $\mathrm{Zn}$ in Mugla province (Turkey). Pakistan Journal of Botany, 40 (4), 1767-1776.

Alloway B.J. (2013) Sources of Heavy metals and metalloids in soil. In: B.J. Alloway (Ed.) $2^{\text {nd }}$ ed., Blackie Academic and Professional, London, pp $11-50$.

Alloway, B.J. and Steinnnes, E. (1999) Anthropogenic addition of cadmium in soils. In: Mc Laughlin MJ, Singh BR (Ed.) Cadmium in Soils and Plants. Kluwer Acad Publ London, pp 97-123.

Ashworth, D.J. and Alloway, B.J. (2004) Soil mobility of sewage sludge-derived dissolved organic matter, copper, nickel and zinc. Environ. Pollut. 127, 137 144.

Aucejo, A., Ferrer, J., Gabaldón, C., Marzal, P. and Seco, A. (1997) Diagnosis of boron, fluorine, lead, nickel and zinc toxicity in citrus plantations in Villarreal, Spain. Water, Air, and Soil Pollution 94, 349-360.

Awofoluor, O.R. (2004) Impact of automobile exhaust on levels of lead in a commercial food from bus terminals in Lagos. Int'l J. Appl. Sci. Environ. Manag. 8 (1), 23-27.

Baker, A.J.M. and Brooks, R.R. (1989) Terrrestrial higher plants which accumulate metallic elements a review of their distribution ecology,and: phytochemistry, Biorecovery 1, 81-126.

Bakkaus, E., Gouget, B., Gallien, J.P., Khodja, H., Carrot, F., Morel, J.L. and Collins, R. (2005) Concentration and distribution of cobalt in higher plants: The use of micro-PIXE spectroscopy. Nuclear Instruments and Methods in Physics Research Section B: Beam Interactions with Materials and Atoms, 231, 350-356.

Caselles, J. (1998) Levels of lead and other metals in citrus alongside a motor road. Water, Air, and Soil Pollution, 105, 593-602.

Chaney, R.L., Chen, K.-Y., Li, Y.-M., Angle, J.S. and Baker, A.J.M. (2008) Effects of calcium on nickel tolerance and accumulation in Alyssum species and cabbage grown in nutrient solution.Plant and Soil, 311, 131-140.
Collins, R.N. and Kinsela, A.S. (2011) Pedogenic factors and measurements of the plant uptake of cobalt. Plant and Soil, 339, 499-512.

Eckel, H., Roth,U., Döhler, H., Nicholson, F. and Unein, R. (2005) Assessment and Reduction of Heavy Metal Input into Agro-ecosystem. Final report EU-concerted Action AROMIS , KTBLSchrift. Publication No. 432, Darmstadt, Germany.

FAO and WHO (2001) Food Additives and Contaminants, Joint Codex Alimentarius Commission, FAO/WHO. Food Standards Programme, ALINORM 01/12A, The Netherland. [Available at: http://www.fao.org/3/a-i1400e.pdf].

Grigalavičienė, I, Rutkovienė, V. and Marozas, V. (2005). The accumulation of heavy metals $\mathrm{Pb}, \mathrm{Cu}$ and $\mathrm{Cd}$ at roadside forest soil. Pol. J. Environ. Stud. 14 (1), 109-115

Grimshaw, H.M. (1987) The determination of total phosphorus in soils by acid digestion. In: Rowland, A. P., (Ed.) Chemical Analysis in Environmental Research. Abbotts Ripton, NERC/ITE, 92-95. (ITE Symposium, 18).

Hansmann, W. and Köppel, V. (2000) Lead-isotopes as tracers of pollutants in soils. Chemical Geology, 171(1-2), 123-144.

Huseyinova, R., Kutbay, H.G., Bilgin, A., K1lıc, D., Horuz, A. and Kirmanoğlu, C. (2009) Sulphur and some heavy metals content in foliage of Corylus avellana and some road side native plants in Ordu province, Turkey. Ekoloji 18 (70), 10-16.

IADSA(1995) CODEX STAN 193-1995 Codex general standard for contaminants and toxins in food. International Alliance of Dietry/Food Supplement Associations IADSA.

Jolly, Y.N., Islam, A. and Akbar, S. (2013) Transfer of metals from soil to vegetables and possible health risk assessment. SpringerPlus, 2, 385.

Kabata-Pendias, A. and Mukherjee, A.B. (2007) Trace Elements from Soil to Human. Springer-Verlag, Berlin, Germany.

Kabata-Pendias, A. and Pendias, H. (1999)Biochemistry of Trace Elements. $2^{\text {nd }}$ ed. Wyd Nauk PWN, Warszawa (in Polish)

Kabata-Pendias, A. and Sadurski, W. (2004) Trace elements and compounds in soil. In: Merian E., Anke M., Ihnat M., Stoepppler M. (Ed.) Elements and their Compounds in the Environment. Wiley$\mathrm{VCH}$, Weinheim, $2^{\text {nd }}$ ed., pp79-99.

Egypt. J. Soil Sci. 57, No. 2 ( 2017 ) 
Kabata-Pendias, A. (1995) Agricultural problems related to excessive trace metal contents of soils. In: Förstner, U., Salomons, W., Mader, P. (Ed.), Heavy Metals: Problems and Solutions. Springer Berlin Heidelberg, pp. 3-18.

Karlsson, H.L. (2004) Ammonia, nitrous oxide and hydrogen cyanide emission from five passenger vehicles. Sci. Total Environ. 334-335, 125-132.

Kartel, M.T., Kupchik, L.A. and Veisov, B.K. (1999) Evaluation of pectin binding of heavy metal ions in aqueous solutions. Chemosphere, 38, 2591-2596.

Leita, L., De Nobili, M., Cesco, S. and Mondini, C. (1996) Analysis of intercellular cadmium forms in roots and leaves of bush bean. J. Plant Nutr. 19, 527-533

Lindsay, W.L. and Norvell W.A. (1978) Development of DTPA soil test for zinc, iron, manganese and copper. Soil Sci. Soc. Am. J. 42, 421-428.

Lone, M. I., He, Z., Stoffella, P. J., and Yang, X. (2008) Phytoremediation of heavy metal polluted soils and water: Progresses and perspectives. J. Zhejiang Univ. Sci. B9 (3), 210-220.

Mamma, D. and Christakopoulos, P. (2014) Biotransformation of citrus by-products into value added products. Waste Biomass Valori. 5, 529-549.

Marín, A.B.P., Ortuño, J.F., Aguilar, M.I., Meseguer, V.F., Sáez, J. and Lloréns, M. (2010) Use of chemical modification to determine the binding of $\mathrm{Cd}(\mathrm{II}), \mathrm{Zn}(\mathrm{II})$ and $\mathrm{Cr}(\mathrm{III})$ ions by orange waste. Biochem. Eng. J. 53, 2-6.

Marschner, H. (Ed.) (1995) Mineral Nutrition of Higher Plants. Academic Press, London.

Martínez García, M.J., Moreno-Grau, S., Martínez García, J.J., Moreno, J., Bayo, J., Guillén Pérez, J.J., and Moreno-Clavel, J. (2001) Distribution of the metals lead, cadmium, copper and zinc in the top soil of Cartagena, Spain. Water Air Soil Poll. 131, 329-347.

Miller, Jr., G.T. (2007) Living in the Environment: Principles, Connections, and Solutions. $15^{\text {th }}$ edition. Thomson Brook/Cole, Belmont, CA

Möller, A., Müller, H.W., Abdullah, A., Abdelgawad, G. and Utermann, J. (2005) Urban soil pollution in Damascus, Syria: concentrations and patterns of heavy metals in the soils of the Damascus Ghouta. Geoderma, 124(1-2), 63-71.

Nabulo, G., Oryem-Origa, H. and Diamond, M. (2006) Assessment of lead, cadmium, and zinc Egypt. J. Soil Sci. 57, No. 2 ( 2017 ) contamination of roadside soils, surface films, and vegetables in Kampala City, Uganda. Environ. Res. 101(1), 42-52.

Nasseem, M.G. and Abdalla, Y.H. (2003) Cobalt status in the north western coast soils of Egypt in relation to cobalt content of barley for ruminants. $6^{\text {th }}$ Inter. Symp. Environ. Biogeochem. Edynburgh.

Nishizono, H., Kubota, K., Suzuki, S. and Ishii, F. (1989) Accumulation of heavy metals in cell walls of Polygonum cuspidatum roots from metalliferous habitats. Plant Cell Physiol. 30, 595-598.

Page, V. and Feller, U. (2015) Heavy metals in crop plants: Transport and redistribution processes on the wholeplant level. Agronomy, 5, 447-463.

Pagotto, C., Rémy, N., Legret, M. and Le Cloirec, P. (2001) Heavy metal pollution of road dust and roadside soil near a major rural highway. Environ. Tech. 22(3), 307-319.

Radulescu, C., Stihi, C., Barbes, L., Chilian, A. and Chelarescu, E.D. (2013) Studies concerning heavy metals accumulation of Carduusnutans L. and Taraxaucmofficinale as a potential soil bio indicator species.REV. CHIM. (Bucharest) 64(7), 754-760.

Romero, A., González, I. and Galán, E. (2012) Trace elements absorption by citrus in a heavily polluted mining site. J. Geochem. Explor. 113, 76-85.

Salt D.E., Kato, N., Kräemer, U., Smith, R.D., and Raskin, I. (1999) The role of root exudates in nickel hyper accumulation and tolerance in accumulator and non-accumulator species of Thlaspi. In: N. Terry, G. Banuelos (Ed.). Phytoremediation of contaminated soil and water. Lewis Publishers, Boca Raton, FL, 189 - 200.

Sanità di Toppi, L. and Gabbrielli, R. (1999) Response to cadmium in higher plants. Environ. Exp. Bot. 41, $105-130$

Sahrawat, K.L., Kumar, G.R. and J. K. and Rao, J.K. (2002) Evaluation of triacid and dry ashing procedures for determining potassium, calcium, magnesium, iron, zinc, manganese, and copper in plant materials. Comm. Soil Sci. Plant Anal. 33 (1-2), 95-102.

Sêkara, A., Poniedzialek, M., Ciura, J. and Jêdrszczyk, E. (2005) Cadmium and lead accumulation and distribution in the organs of nine crops: Implications for phytoremediation. Polish J. Environ. Studies $14,509-516$

Sezgin, N., Ozcan, H.K., Demir, G., Nemlioglu, S. and Bayat, C. (2004) Determination of heavy metal concentrations in street dusts in Istanbul E-5 
highway. Environ. Inter. 29 (7), 979-985.

Shea, E.E. (1996) Lead Regulation Handbook. Government Institutes Inc., Rockville, MD, 240.

Shen, Z.-G., Li, X.-D., Wang, C.-C., Chen, H.-M. and Chua, H. (2002) Lead phytoextraction from contaminated soil with high-biomass Plant Species. J. Environ. Quality, 31, 1893-1900.

Singh, S., Zacharias, M., Kalpana, S. and Mishra, S. (2012) Heavy metals accumulation and distribution pattern in different vegetables crops. J. Environ. Chem. Ecotoxicol. 4 (10), 170-177.

Sinha, P., Dube, B.K., Srivastava, P. and Chatterjee, C. (2006) Alteration in uptake and translocation of essential nutrients in cabbage by excess lead. Chemosphere, 65, 651-656.

Su, D.-C., Jiao, W.-P., Zhou, M. and Chen, X. (2010). Can cadmium uptake by Chinese cabbage be reduced after growing $\mathrm{Cd}$-accumulating rapeseed. Pedosphere, 20, 90-95.

Tangahu, B.V., Abdullah, S.R.S., Basri, H., Idris, M., Anuar, N. and Mukhlisin, M. (2011) A Review on heavy metals $(\mathrm{As}, \mathrm{Pb}$, and $\mathrm{Hg})$ uptake by plants through phytoremediation. Inter. J. Chem. Eng. doi:10.1155/2011/939161

Thomaidis, N.S., Bakeas, E.B. and Siskos, P.A. (2003) Characterization of lead, cadmium, arsenic and nickel in PM2.5 particles in the Athens atmosphere, Greece. Chemosphere, 52 (6), 959-966.

Uchida, S., Tagami, K. and Hirai, I. (2007) Soil-to-plant transfer factors of stable elements and naturally occurring radio nuclides: (2) rice collected in Japan. J. Nucl. Sci. Technol, 44, 779-790.

UNEP (2000) Global environment Outlook. Earth Scan Publications Ltd, London; pp133-133.
Welch, R.M. and Shuman, L. (1995) Micronutrient nutrition of plants. Crit. Rev. Plant Sci. 14, 49-82.

WHO (1995) Trace elements in human nutrition and health. World Health Organization, Geneva, Available at: http://www.who.int/nutrition/ publications/micronutrients/9241561734/en/

WHO (2006) Cobalt and inorganic cobalt compounds. Concise International Chemical Assessment Document 69, World Health Organization. Available at: http://www.who.int/ipcs/publications/ cicad/cicad 69\%20.pdf

Wuana, R.A. and Okieimen, F.E. (2011) Heavy metals in contaminated soils: A review of sources, chemistry, risks and best available strategies for remediation. ISRN Ecology 2011, 20.

Xian, X. (1989) Effect of chemical forms of cadmium, zinc, and lead in polluted soils on their uptake by cabbage plants. Plant Soil, 113, 257-264.

Young, S.D. (2013) Chemistry of heavy metals and metalloids in soils. In: Alloway, J.B. (Ed.), Heavy Metals in Soils: Trace Metals and Metalloids in Soils and their Bioavailability. Springer Netherlands, Dordrecht, pp. 51-95.

Yusuf, M., Fariduddin, Q., Hayat, S. and Ahmad, A. (2011) Nickel: An overview of uptake, essentiality and toxicity in plants. B. Environ. Contam. Tox. 86, $1-17$.

Zhang, M.K., He, Z.I., Calvert, D.V. and Stoffella, P.J. (2004) Leaching of minerals and heavy metals from muck amended sandy soil columns. Soil Sci. 169, 528-540.

(Received:12/10/2016; accepted: $5 / 2$ /2017) 


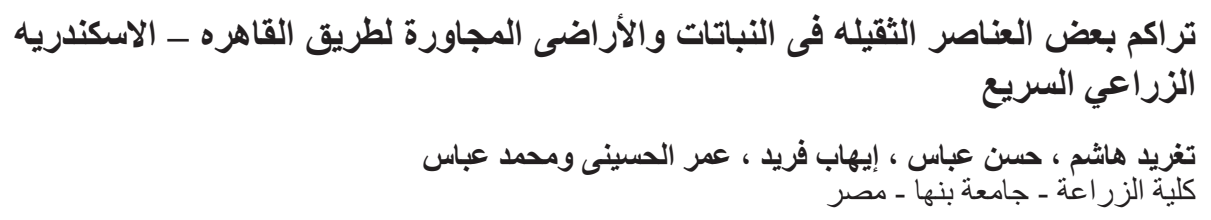

تعتبر عو ادم السيار ات المصدر الرئيسي لتلوث الهو اء بالعناصر التقبله ، و التي تتسبب في ظهور مشكلات بيئية

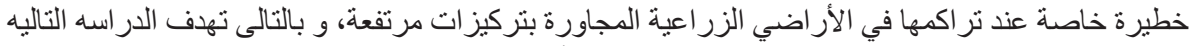

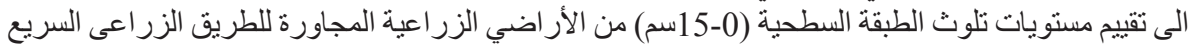

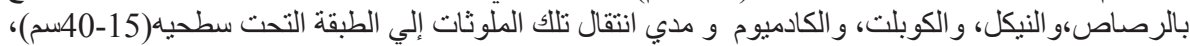

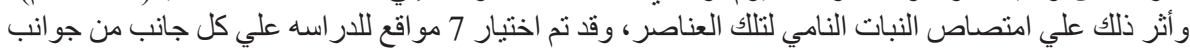

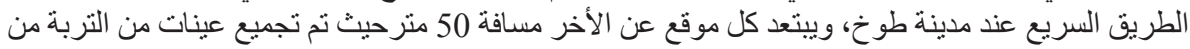

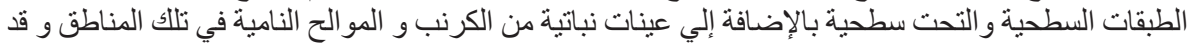

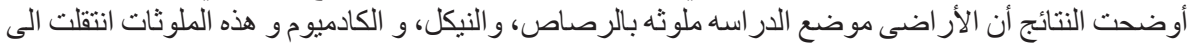

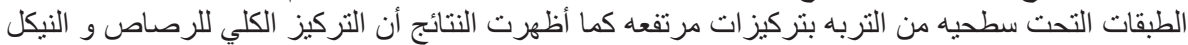

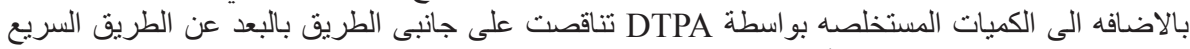

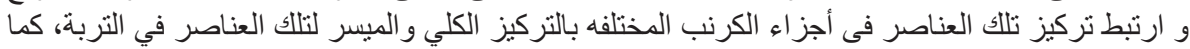

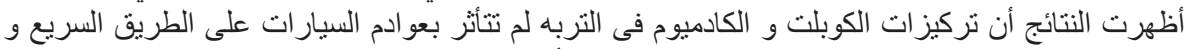

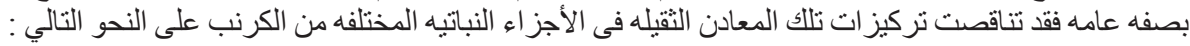

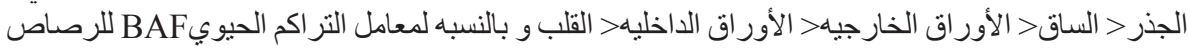

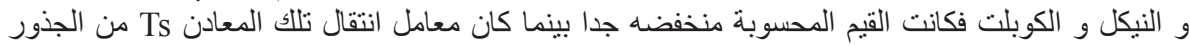

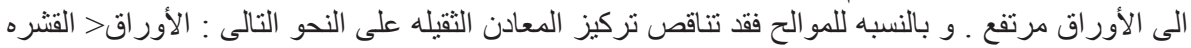

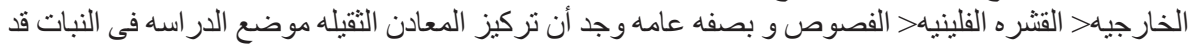
تجاوزت الحدود المسموح بها خاصه بالنسبه لعنصر الرهاص الرصاص. 